\title{
The Promise and Failure of the American Dream in Scott Fitzgerald's Fiction
}

\author{
Parvin Ghasemi \\ Department of Foreign Languages and Linguistics, Faculty of Literature and \\ Humanities, Shiraz University, Pardis Eram, Shiraz 71944, Iran. \\ e-mail: pghasemi2000@yahoo.com, pghasemi54@gmail.com, \\ pghasemi@rose.shirazu.ac.ir \\ Mitra Tiur \\ Department of Foreign Languages and Linguistics, Faculty of Literature and \\ Humanities, Shiraz University, Pardis Eram, Shiraz 71944, Iran. \\ e-mail: mitra.tiur@gmail.com
}

\begin{abstract}
The Great Gatsby is Fitzgerald's best fictional account of the promise and failure of the American dream because here the congruity of story and style and attitude is most meaningful to the depiction of this theme. Fitzgerald created Gatsby and his myth to be an emblem of the irony and the corruption of the American dream. Fitzgerald was the embodiment of the fluid polarities of American experience: success and failure, illusion and disillusion, dream and nightmare. The exhaustion of the frontier and the rebound of the post war expatriate movement marked for Fitzgerald as the end of a long period in human history, the history of the Post-Renaissance man in America, that he made the substance of his works. Fitzgerald's ideology, a serious criticism on the American Dream, reveals the real nature of American life so that he could find a way to the truth of the American identity.
\end{abstract}

Key words: American Dream, corruption, success and failure, illusion and disillusion, Jazz Age, ideology, criticism, American identity.

To analyze the core idea of the concept of the American Dream (more precisely its emergence as a prevalent social concern during the 1920s), many relevant factors have to be taken into account and studied. The elements worth of consideration are those responsible for creating, reinforcing, and consequently corroding the phenomenon. Among these the post-war social conditions of the era stand as the most prominent. In 
other words, a general survey in social history of the twenties would provide a better grasp on the illusions pervading the society. According to Cleanth Brooks (1973):

Historically, the 1920s were not only an age of disillusionment and frenetic excitement; they were also an age of vital creativity and intellectual development..... But the world in which he [Fitzgerald] did immerse himself he reported as faithfully and came to judge as honestly, as he could. If he was relatively ignorant of the great forces that were shaking that world, he did have an acute sense for "felt" history, for the trauma that those forces set up in the unconscious of individuals and of society; it is significant that T.S. Eliot, the author of The Waste Land, was a devoted admirer of The Great Gatsby, Fitzgerald's third and best novel (p. 2284).

Anthony Patch, a character in The Beautiful and Damned (1922) expresses the positive aspect of the twenties' attitude by the phrase, "lustreness and unromantic haven" (p. 41). To agree with Mizener (1963), Fitzgerald probably better than any other writer had depicted his feeling, this vision of a lustrous and romantic haven which seemed "rosy and romantic to us who were young then," and the feeling that when defeat came, "it was because a stubbornly unimaginative society with an incurable preference for a meretricious life prevented people capable of imagining this haven from achieving it" (p. 93).

The Great Gatsby is Fitzgerald's best fictional account of the promise and failure of the American dream because here the congruity of story and style and attitude is closest and most meaningful to the depiction of this theme. According to Sven Birkerts (2006), "The Great Gatsby is, most of us would agree, beautifully self-contained, with all its parts echoing each other and at the same time serving the whole" (p. 3). Here he had a story whose central character not only symbolized his own conflicts and confusions, but made a moving commentary on a period and a country as well. The grandeur and pathos of Gatsby are that his enormous vitality, ambition and power of creation are all lavished on a "vast, vulgar, and meretricious beauty" unworthy of the emotion that cannot discover a worthier ideal. It is notable that the auditors clearly, and even Gatsby dimly, are aware of the corruption "concealing his incorruptible dream" (GG, p. 125). If the feeling of the novel owes a 
good deal to its author's identification with his subject, its impact owes a lot too to its range, to the fact that Gatsby is not merely a disguise for Fitzgerald. Not only Gatsby and Fitzgerald have dreams nobler and finer than any tangible forms that are given them, or that they can find for them, but they are more charged with emotion than the tangible forms justify. The tragedy of Gatsby was a fable for his America which is not by any means dead yet.

It is a common belief that Fitzgerald created Gatsby and his myth to be an emblem of the irony of American history and the corruption of the American dream. At the core of the legend embodying Gatsby, he implants the relationship between Europe and America and the ambiguous interactions between the prevalent conflicting tendencies of Europe which resulted in the ingenious foundation of America in the first place, and its subsequent development: mercantilism and idealism. American history has invariably been the scene on which these two impulses have been displayed as having a way of being both radically exclusive and mutually confusing, the one melting into the other: the man's heightened capacity for wonder, on the one hand, and the enchanting power and splendor of things on the other. After Gatsby's death only Gatsby himself seems to Nick Carraway to have been alright and "what preyed on Gatsby, what foul dust floated in the wake of his dreams ..." (GG, p. 135) is to be blamed for the disaster.

Gatsby's vision of "a romantic haven" constructed on his "extraordinary gift for hope, his romantic readiness and his heightened sensibility to the promises of life" was doomed to failure because it only had "a vast vulgar, meretricious beauty" made out of the materials Gatsby's society provided him. In Fitzgerald's time his kind of romantic haven was "that a seventeen year old boy would be likely to invent"; a world peopled with those "who do interesting things, celebrated people," like "Mr. Buchanan, the polo player" and Jordan Baker, the "great sports woman" who would "never do anything that wasn't all right," whereas "Tom Buchanan," in Mizener's words, "is in fact a vicious, self-deceived sentimentalist and Jordan Baker and incurable liar and cheat" (p. 88). With the insistence on the necessity of the belief in the possibility of a meaningful existence and the world's conspiring to make such a belief impossible, Fitzgerald tries to speak for his own time and maybe for all generations of Americans as the ending of The Great Gatsby indicates: 
... Gatsby believed in the Green light, the organistic future that year

by year recedes before us. It eludes us then, but that's no matterTomorrow we will run faster, stretch out our arms farther .... And so one fine morning -

So we beat on, boats against the current, borne back ceaselessness into the past (GG, p. 137).

As Trilling (1950) notes, the writers of the twenties strove to write truthfully about the inner experience of Americans and doing so, they hoped their novels would gain appreciation and importance:

Their subject was the making of Americans, in a sense very different from the merely political one - the notion that Americans were 'new men', the products of a novel social experiment which had dominated men's imaginations in previous generations (p. 185).

Fitzgerald, one of the most outstanding figures of the twenties, completed the cycle of his life by reproducing the design of an entire literary movement. But Fitzgerald was more than merely typical of that movement: he was its most sensitive and tormented talent and the prophet of its doom with a sense of the destructive impulses of his time that can only be compared with a Hemingway's; yet, he lacked Hemingway's stabilizing gift- the ability to get rid of the bad times by writing of them. Fitzgerald never got rid of anything; the ghosts of his adolescence, the failures of his youth, and the doubts of his maturity played him to the end. He was supremely a part of the world he described, so much a part that he made himself its king and then, when he saw it begin to crumble, he crumbled with it and led it to death.

Fitzgerald, who was stripped of his luck and illusions, neither had the guts to keep it to himself nor the talent to forge new ones. But where others merely lost themselves, Fitzgerald knew where he was lost. He knew what they did not know - that from this maze there was no way out. It was neither fatigue nor the aimless wandering, but the paralysis of will that grew out of the knowledge that the past was dead, and that the present had no future.

The conflicts within Fitzgerald's character and work have always fascinated readers since the first stirrings of Fitzgerald's revival in the 1940s. Critics have focused their studies upon these oppositions to 
explore the origins and fate of the American dream and the related idea of the nation. What he experienced as personal contradictions intensified the implications of the dream for individual lives implanted in the novels and fictions he created: the promise and possibilities, violations and corruptions of the ideals of nationhood and personality. As James (2005) contends,

Though Fitzgerald is particularly known for his historical sense, his use of the war is far from idiosyncratic. What is idiosyncratic, I think, is the self-consciousness with which Fitzgerald's novel demonstrates the manipulation of history as a strategy to accommodate gender anxiety. In a variety of discourses and media, the postwar era saw a new myth of war experience, which was used to stereotype male suffering as disillusionment (p. 31).

Fitzgerald was the embodiment of the fluid polarities of American experience: success and failure, illusion and disillusion, dream and nightmare. Fitzgerald, who named and chronicled that brash, schizophrenic decade, was no stranger to the dissipation of values and the pursuit of sensation in the Jazz Age of the 1920s. To him it was not simply existence and the soul's dark night of melancholia and despair. It also stood for an American reality that combined with "an extraordinary gift for hope" and a "romantic readiness" led to the extravagant promising identified with America and the intense, devastating loss felt when the dream fails in one or another of its guises.

Fitzgerald, as a writer, looked beyond his circumstances and saw the American Dream not as a personal matter and no longer a nostalgic romantic possibility but as a continuing defining characteristic of the American nation and its people. Far from being behind him as Nick Carraway had claimed in The Great Gatsby, the dream is a recurring phenomenon in each phase, place and guise of Fitzgerald's imagination of American experience.

The American story, Fitzgerald wrote late in life, "is the history of all aspiration, not just the American dream but the human dream ..." (The Crack-Up, 1945, p. 64). The story that Fitzgerald told was his version of a dream hauntingly personal and national. "When I was your age," he wrote his daughter in 1938, "I lived with a great dream. The dream grew and I learned how to speak of it and make people listen" (p. 37). Like 
John Keats, who, Fitzgerald imagined, was sustained to the end by his "hope of being among the English poets" (p. 81), Fitzgerald aspired to be among the great novelists.

In its American guise, the dream Fitzgerald sought to realize flowed from that most elusive and original of the rights proclaimed by the Declaration of Independence. Framed as an "unalienable" right by Thomas Jefferson and espoused by the other founders of this revolutionary nation, the "pursuit of happiness" magnified the American Dream into an abiding, almost sacred promise. It is striking to note that although Jefferson amended John Locke's "life, liberty, and property or estate" to "Life, liberty, and the pursuit of happiness", nobody explained or remarked in writing on the change. However, naming the "pursuit of happiness" an unalienable right confirmed the newly declared American nation as an experimental, necessarily improvisational society dedicated to the principle that every human personality is sacred and inviolable. Yes, blacks, women, Native Americans, and even indentured servants were excluded, but excluded then, not forever. For as Lincoln was to imply in the Gettysburg Address, the Declaration's eloquent language strained toward the proposition that all persons were free; therefore, implicated in and responsible for the nation's destiny. The idea and covenant of American citizenship required that all individuals make themselves up in the midst of the emerging new society, and the process of creation would be vernacular, arising from native ground, the weather, landscape, customs, habits, peoples, and values of this new world in the making.

That was and remains the promise of America. But Fitzgerald's novels remind us that things were never this simple. A democracy is always accompanied by its contradiction which as Burnam (1952) explicates: "One such contraction unresolved by the Declaration or the ensuing constitution, and played out since in national experience and Fitzgerald's novels are between property and the pursuit of happiness" (p. 139). For some the "pursuit of happiness" was simply a euphemism for property. Officially, the tension went unresolved and scarcely acknowledged until the $14^{\text {th }}$ Amendment forbade the states to "deprive any person of life, liberty, or property, without due process of law." The less concrete, the more elusive, "pursuit of happiness" went unmentioned except by implication. Left, for over 200 years, before and after passage of the $14^{\text {th }}$ Amendment, Americans have sought to balance property's 
material reality with the imaginative possibilities hinted at in the phrase the "pursuit of happiness".

What if we were to read Gatsby and Tender Is the Night as the projection of that sometime struggle, sometime alliance between property and the pursuit of happiness? As human impulses, property and the pursuit of happiness are sometimes contradictory, sometimes complementary metaphors for experience. Let property stand for the compulsion to divide the world and contain experience within fixed, arbitrary boundaries and let the "pursuit of happiness" become imagination's embrace of the complexity, fluidity, and possibility open to human personality. In Jefferson's time, if not so strongly in Fitzgerald's or contemporary times, the "pursuit of happiness" also implied individual responsibility for the "spirit of public happiness" that John Adams felt so strongly in the colonies so that he judged the American Revolution won almost before it began. Jefferson did not include the word public, but his phrase implies the individual's integration of desire with responsibility, self-fulfillment with the work of the world. In short, in this promissory initial American context, the pursuit of happiness was bound up with citizenship and citizenship with each individual's responsibility for democracy.

Along with social considerations in this regard, come social structures and distinctions, "the novelist of certain kind". Trilling suggests, "if he is to write about social life, may not brush away the reality of the differences of class, even though to do so may have the momentary appearance of a virtuous social avowal" (p. 247).

Fitzgerald, though despising class differences, was always fascinated and absorbed by them and in his novels he could never leave off the themes which would deal with this essence of the preoccupation of his mind. Although it is believed that social position must never be taken seriously in literature, its impact can always be observed in the art of great writers from Homer to Fitzgerald, who nurtured the theme of the Idealistic dream through different means mostly by Romantic fantasy of personal ambition and heroism, of life committed to or thrown away for some ideal of self. Today, this sort of idealism appears as only a boyish dream to the youth who are required to find social distinctions through cooperation, subordination, and an expressed piety of social usefulness.

In other words, what Fitzgerald pursues as the basic plot of his novels is the history of the new world or of the human imagination in the 
new world if we are to read American history as the tale of the romantic imagination in the United States depicted in two predominant patterns, quest and seduction. The quest is the search for romantic wonder, in the terms proposed by contemporary Americans. The seduction represents capitulation to these terms. Simultaneously, the quest is a flight: from reality, normality, time, fate, death, and the conception of limit, in the social realm, the pattern of desire may be suggested by such phrases as "the American dream," and "the pursuit of happiness" as went before. Fitzgerald begins by exposing the corruption of that dream in industrial America; he ends by discovering that the pursuit is universally seductive and perpetually damned. Driven by inner forces that compel him towards the personal realization of Romantic wonder, the Fitzgerald hero is destroyed by the materials which the American experience offers as objects and criteria of passion, or, at best, he is purged of these unholy fires, chastened and reduced.

In general, this quest has two symptomatic goals. There is, for one, the search for eternal youth and beauty. The essence of romantic wonder appears to reside in the illusion of perennial youth and grace and happiness surrounding the leisure class of which Fitzgerald customarily wrote. Thus, the man of imagination in America, searching for the source of satisfaction of his deepest aesthetic needs, is seduced by the delusion that these qualities are actually to be found in people who, in sober fact, are vacuous and irresponsible. But further, this kind of romantic quest, which implies both escape and destruction, is equated on the level of national ideology with a transcendental and Utopian contempt for time and history, and on the religious level, which Fitzgerald persistently but hesitantly approaches, with a blasphemous rejection of the very conditions of human existence.

The second goal is, simply enough, money. The search for wealth is the familiar Anglo-Saxon Protestant ideal of personal material success, most succinctly embodied for the American culture in the saga of young Benjamin Franklin. It is the romantic assumption of this aspect of the "American dream" that all the magic of the world can be had for money. Both from a moral, and from a highly personal and idiosyncratic standpoint, Fitzgerald examines and condemns the plutocratic ambitions of American life and the ruinous price exacted as to be for all practical purposes one: the appearance of eternal youth and beauty centers in a particular social class whose glamour is made possible by social 
inequality and inequity. Beauty, the presumed object of aesthetic contemplation, is commercialized, love is bought and sold. Money is the means to the violent recovery or specious arrest of an enchanting youth.

In muted contrast, Fitzgerald repeatedly affirms his faith in an older, simpler America, generally identified as pre-Civil War; the emotion is that of pastoral, the social connotations agrarian and democratic. In such areas, he continues to find fragments of basic human value, social, moral, and religious. But these affirmations are for the most part subordinate and indirect; Fitzgerald's attention was chiefly directed upon the merchandise of romantic wonder proffered by his own time and place. Like the narrator in Gatsby, he was always "within and without, simultaneously enchanted and repelled by the inexhaustible variety of life" (GG p. 28). Through a delicate and exact imagery he was able to extend this attitude of simultaneous enchantment and repulsion over the whole of the American civilization he knew. His keenest perception, and the one that told most heavily for his fiction, was the universal quality of the patterns he was tracing, his greatest discovery that there was nothing new about the Lost Generation except its particular toys. The quest for romantic wonder and the inevitable failure was only the latest in a long series.

Fitzgerald's general intention of using the pervading symbol of light in his novels (more specifically at the end of The Great Gatsby) is to measure the behavior and attitudes of the Lost Generation with a symbol of romantic wonder extensive enough to comprehend all American experience as far back as 1492. The contrast involves the ironic rejection of all that this present generation believes in, the immaturity and triviality of its lust for pleasure. But then, by a further turn of irony, the voyage of Columbus and his discovery of the Western Hemisphere is also the actual event forming the first link in the chain leading to the butt-end of contemporary folly. There is the further implication that some sort of conscious search is at the heart of American experience, but had never before taken so childish a form. What Fitzgerald is almost certainly trying to say with this image is: this is the end of Columbus' dream, and this is the American's brave new world.

Accordingly, some points are to be buttressed for the purposes documentation to provide a brighter view on the issue discussed above. The most important thing to observe is probably that Fitzgerald saw in the quest for romantic wonder a recurrent pattern of American behavior. "You speak of how good your generation is", Fitzgerald once wrote his 
daughter, "but I think they share with every generation since the Civil War in America the sense of being somehow about to inherit the earth. You've heard me say before that I think the faces of most American women over thirty are relief maps of petulant and bewildered unhappiness" (The Crack-Up, p. 306).

Later in his notebooks he gives more elaborations on the "sense of being about the inherit the earth": "her [America's ] dominant idea and goal is freedom without responsibility, which is like gold without metal, spring without winter, youth without age, one of those maddening, coocoo mirages of wild riches" (p. 166). That this personal attitude, translated into the broader terms of a whole culture, represented a negation of historical responsibility is made sufficiently clear in another note-book passage: "Americans, he liked to say, should be born with fins, and perhaps they were - perhaps money was a form of fin. In England, property begot a strong place sense, but Americans, restless and with shallow roots, needed fins and wings. There was even a recurrent idea in America about an education that would leave out history and the past, that should be a sort of equipment for aerial adventure, weighed down by none of the stowaways of inheritance or tradition" (p. 109).

Still another passage, this time from one of Crack-up essays, makes it equally clear that Fitzgerald habitually saw the universal applicability of all he was saying about the ruling passions of America: "This is what I think now: that the natural state of the sentient adult is a qualified unhappiness. I think also that in an adult the desire to be finer in grain than you are. 'A constant striving' only adds to this unhappiness in the end that end that comes to our youth and hope" (p. 184).

Fortunately, Fitzgerald was never a cynic. For all the failure of futility he found in the American experience, his attitude was an attitude of acceptance. There was always in him something of Jimmy Gatz's "extraordinary gift of hope", which enabled him to touch the subjects he touched without being consumed by them (speaking only of his heroism and integrity as an artist rather than the tragedies of his personal life). As Barbara Will (2005) has put it aptly, "it is in the final, lyrical paragraphs of the novel that Gatsby's fate takes on mythic dimensions, becoming an allegory for the course of the American nation and for the struggles and dreams of its citizens (p. 125).

The exhaustion of the frontier and the rebound of the post war expatriate movement marked for Fitzgerald the end of a long period in 
human history and it was really this entire period, the history of the PostRenaissance man in America, that he made the substance of his works. After exploring his materials to their limits, Fitzgerald knew, at his greatest moments, that he had discovered a universal pattern of desire and belief and behavior, and that in it was compounded the imaginative history of modern especially American Civilization.

\section{REFERENCES}

Birkerts, S. (2006). Serving the sentence. Raritan, 25, 1- 11.

Brooks, C. (1973). American literature: The makers and the making. Book D, 1914 to the present. New York: St. Martin's Press.

Burnam, T. (1952). The eyes of Dr. Eckleburg: A re-examination of the great gatsby. College English, 14, 7-12.

Fitzgerald, F. S. (1945). The crack-up (E. Wilson, Ed.). New York: New Directions. . (1922). Beautiful and damned. New York: Scribner's . (1925). The great Gatsby. New York: Scribner's. . (1964). The letters of F. Scott Fitzgerald (A. Turnbull, Ed.). New York: Scribner's.

. (1978). The notebooks of F. Scott Fitzgerald (M. J. Bruccoli, Ed.). New York and London: Harcourt Brace Jovanovich. . (1934). Tender is the night. New York: Scribner's.

James, P. (2005). History and masculinity in F. Scott Fitzgerald's This side of paradise. Modern Fiction Studies, 51, 1-33.

Mizener, A. (Ed.). (1963). F. Scott Fitzgerald: A collection of critical essays. Englewood Cliffs, New Jersey: Prentice-Hall.

Trilling, L. (1950). The liberal imagination. New York: Viking Press.

Will, B. (2005). The great Gatsby and the obscene word. College Literature, $32,125-146$. 